\title{
CHALLENGES IN THE MANAGEMENT OF EMERGENCY PUBLIC PROCUREMENT PERFORMED IN ROMANIA TO COMBAT THE COVID-19 PANDEMIC
}

\author{
lonel PREDA \\ Bucharest University of Economic Studies, Bucharest, Romania \\ predaionel4@gmail.com
}

\begin{abstract}
The spread of the pandemic generated by the emergence of the new COVID-19 coronavirus quickly became a reality that we cannot ignore and that has caused a series of rapid changes in our personal and professional life, while being a challenge from a managerial point of view. Emergency public procurement has been one of the measures taken by all governments affected by the pandemic to support health systems and limit the spread of the virus. The article analyzes the literature on public procurement in emergency situations and the main features of emergency public procurement management functions. It also describes how public procurement procedures have been simplified in Romania during the state of emergency, the benefits achieved and the problems encountered in conducting procurement procedures to combat the effects of the COVID-19 pandemic.
\end{abstract}

Keywords: Covid-19, emergency public procurement, functions of management, difficulties, corruption.

\section{INTRODUCTION}

Following the emergence and expansion of the COVID-19 pandemic, all affected countries have implemented a number of measures aimed at reducing the rate of spread of the virus and increasing the treatment capacity of hospitals and healthcare systems. One of these measures was to carry out emergency public procurement of sanitary materials and medical equipment (breathing apparatus, protective suits, protective masks, protective goggles, visors, disinfectants).

Given the rapid increase in the number of diseases with COVID-19, to prevent virus spread, the governments of the European Union countries have taken a number of measures including declaration of emergency state, prohibition of exports of medical equipment, prohibition of large-scale meetings of persons, suspension of flights, stopping courses in schools and universities and partial closure of borders (OECD, 2020). 
Preda, l.

CHALLENGES IN THE MANAGEMENT OF EMERGENCY PUBLIC PROCUREMENT PERFORMED IN ROMANIA TO COMBAT THE COVID-19 PANDEMIC

Figure 1 shows the evolution of the total number of illnesses and deaths caused by the COVID-19 virus in Romania.

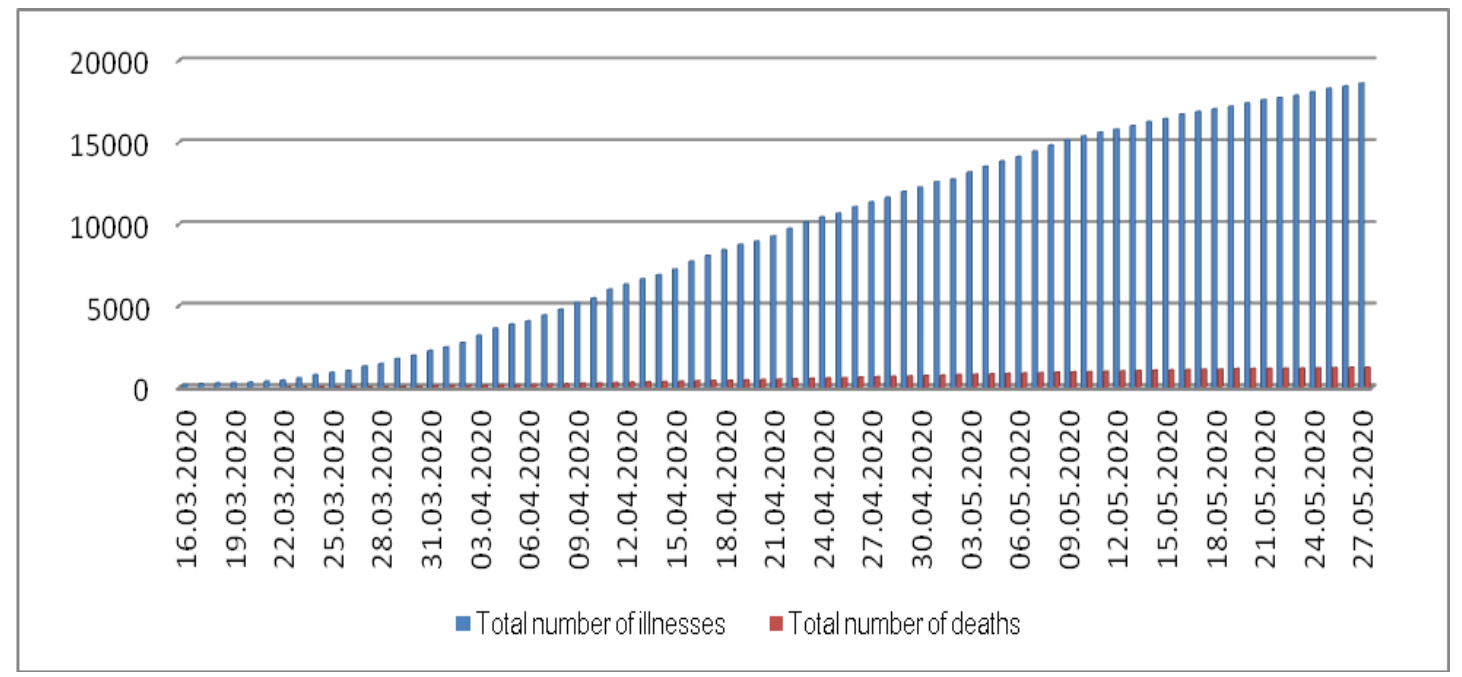

\section{FIGURE 1. THE EVOLUTION OF THE TOTAL NUMBER OF ILLNESSES AND DEATHS}

\section{CAUSED BY THE COVID-19 VIRUS IN ROMANIA}

Source: Health Minister of Romania (2020a)

The measures to combat the COVID-19 pandemic also consisted of very large financial efforts. In Romania, the budgets of the Romanian Ministry of Internal Affairs and the Romanian Ministry of Health were increased by 100 million lei (about 20.4 million euros), respectively 392 million lei (about 80 million euros). Also, the Romanian Ministry of Finance contracted a loan of 1.15 billion lei (about 234.7 million euros) for the emergency procurement of medical equipment required (OECD, 2020).

Given that all procurement in Romania are paid in the national currency (lei) and many medical materials / equipment are imported, one aspect that needs to be analyzed is the currency risk. The context in which emergency procurement were carried out was characterized by the fact that the currency risk during the pandemic period was low. During the emergency and pandemic, the leu / euro exchange rate was stable, with no large variations to negatively affect the procurement.

The national currency (leu) depreciated slightly in January, but less than other currencies in the region (OECD, 2020). Figure 2 shows the evolution of the Euro / leu exchange rate in Romania between 16.03.2020 and 27.05.2020. 


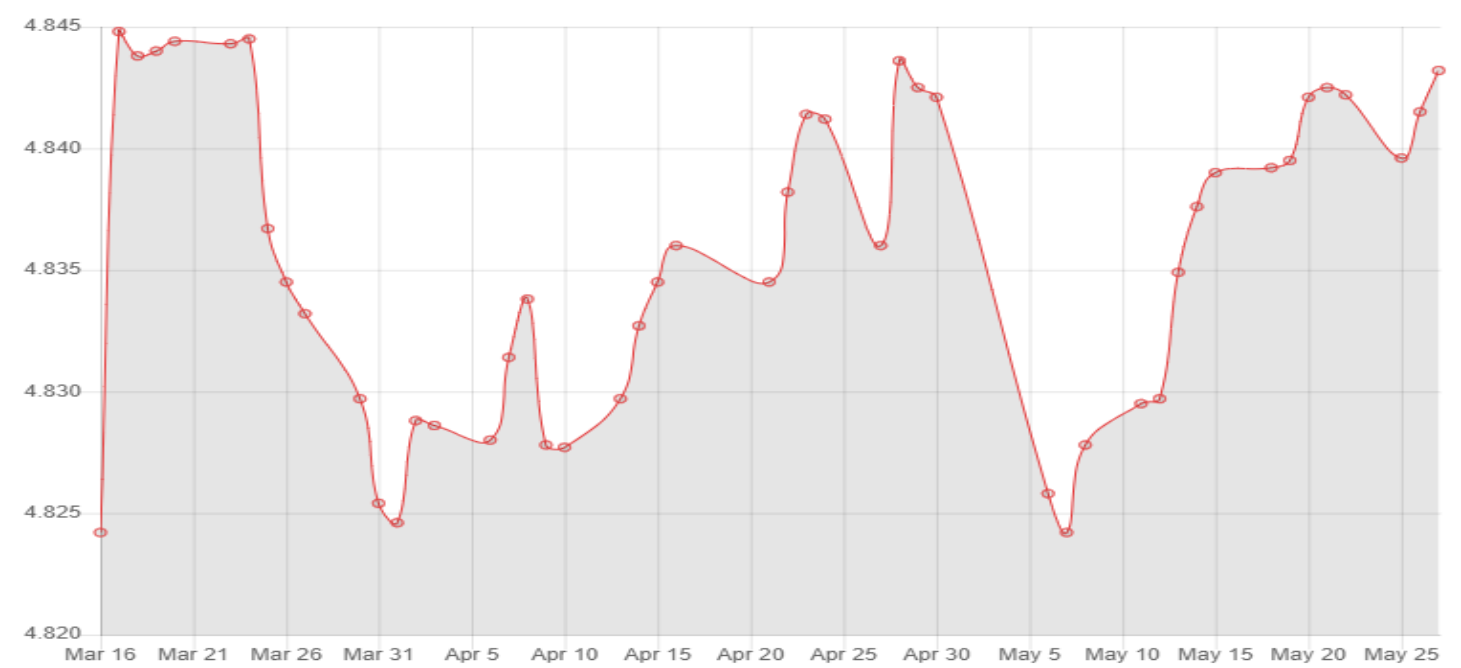

FIGURE 2. THE EVOLUTION OF THE EURO / LEU EXCHANGE RATE IN ROMANIA BETWEEN 16.03.2020 AND 27.05.2020

Source: Expertulbanilor (2020)

The following research is intended to identify and analyze the main issues related to the management of emergency public procurement for the purpose of ensuring the urgent needs of products and services that have arisen in the new context of the COVID-19 pandemic. The main changes in the five functions of the management of public procurement under the Romanian state of emergency are also analyzed.

\section{LITERATURE REVIEW}

The rapid spread of the COVID-19 virus has made people realize how great the threat of a communicable disease to humanity is. To combat this pandemic, a responsive, multifunctional and efficient emergency management system based on global information communication needs to be established. Policies to combat the pandemic must be based on the integration of resources, social mobilization, the provision of funding, the development of vaccines, international cooperation and the provision of medicines, health materials, medical equipment (Jin et al., 2020).

Procurement plays a fundamental role in any organization (Pereira et al., 2014). Public procurement are complex processes that includes planning, carrying out procurement procedures, concluding contracts, delivering products and managing resources and suppliers (Ellram \& Carr, 1994; Lindgreen et al., 2013).

Government procurement plays an important role both during and after crises. Public procurement is indispensable to deal with global economic crises and disasters such as earthquakes, floods and 
Preda, I.

pandemics. Public procurement can restore social and economic stability, optimize the outdated economic structure, stimulate growth for small and medium-sized enterprises (Guang \& Yi, 2012).

Dangerous events (pandemics) and natural disasters (earthquakes, fires, tsunamis) increase restrictions on procurement systems and their inadequate response may have long-term effects on the recovery of affected areas (Atkinson \& Sapat, 2012).

Research on emergency procurement is very limited in Europe. In the US, however, following the terrorist attacks on 11 September 2001, an increasing importance was given to to the management of emergency situations and consequently to emergency procurement (Drabkin \& Thai, 2007). However, research in the field of emergency procurement is limited compared to the importance of the subject (Friar, 2006). For example, Criss (2006) studied strategic supply in urgent conditions, but did not analyze the procurement procedures carried out as a matter of urgency.

Among the various non-clinical activities that take place within a healthcare organization, logistics and procurement activities are of particular importance, as they spend a large proportion of the budgets allocated, being essential for achieving operational performance (Skipworth et al., 2020). In order to reduce the costs of crisis management and improve the efficiency of the process, the introduction of government procurement in public crisis management is necessary (Guang \& Yi, 2012).

Unlike private procurement, public procurement has more procedures, with higher risk aversion and much less flexibility, which are designed around bureaucratic principles (Vyas et al., 2018; Bozeman \& Kingsley, 1998). Public procurement is conducted in compliance with principles such as transparency, non-discrimination and equal treatment to encourage competition and reduce corruption risks (European Parliament, 2014). In the case of public organizations, the added value of procurement is often not the actual results obtained but is assimilated with the way in which procurement procedures have been carried out by contracting authorities (Moore, 1995).

\section{RESEARCH QUESTIONS}

This research seeks to answer the following questions:

1. What are the main features of the management functions in emergency public procurement carried out as a result of the COVID-19 pandemic?

2. How have public procurement procedures in Romania been simplified during the state of emergency?

3. What were the main problems in the context of emergency public procurement?

These questions are important analysis topics for the stakeholders involved in the conduct of emergency public procurement procedures in Romania and worldwide. 


\section{CHARACTERISTICS OF MANAGEMENT FUNCTIONS IN EMERGENCY PUBLIC PROCUREMENT PERFORMED IN THE COVID-19 CRISIS}

Although the management functions have so far been analyzed in various processes or organizations, so far, they have not been analyzed in the framework of the emergency procurement.

The five functions of the management of emergency public procurement (planning, organising, coordonating, commanding, controlling) present a series of particularities that will be presented and analyzed further.

\subsection{THE FUNCTION OF PLANNING EMERGENCY PROCUREMENT}

The planning function aims at the processes through which the main objectives of procurement activities are determined.

Nicolescu \& Verboncu (2008) emphasized that along with the objectives are established their components and the necessary resources and Moga \& Rădulescu (2004) highlighted the role of planning in order to anticipate the problems that may arise from inside or outside the organization. Also, Androniceanu (2005) found that within public institutions, the objectives must be set according to the general and specific public needs, ways of achievement and resources available.

In emergency procurement, financial resources are suddenly increasing while human resources remain unchanged. It greatly increases the pressure on procurers to make a large number of procurement quickly, transparently and efficiently. Anticipating problems is becoming very difficult, if not impossible. Given the rapid evolution of the COVID-19 pandemic, the focus of the planning function shifts from forecasts to rapid intervention programs. The speed of response of procurement systems is essential for the effective implementation of measures to combat the virus spread. And to ensure a very fast response, solutions are needed such as simplifying procurement procedures and reducing the legal deadlines for their conduct.

According to the provisions of Romanian Law No 98/2016 concerning public procurement, the identification of the needs of the contracting authorities is done in the planning / preparation stage of the procurement procedures by elaborating the necessity reports. A first challenge for emergency procurement is to identify general and specific public needs and establish the technical specifications of the products / services to be procured. This aspect becomes very difficult to manage in public authorities which, until the moment of the pandemic have not purchased medical products / equipment, but which, after the emergency situation was established, have to make such procurement.

In the case of regular procurement, the product/service needs for the following year are established in the last quarter of the previous year, based on the necessity reports, drawing up the PAAP (Annual 
Preda, I.

Public Procurement Program), which is necessary to prioritize needs and reserve the necessary resources. In the case of emergency procurement this is no longer possible, and needs are established whenever necessary, as the pandemic unfolds.

Monitoring the portfolio of procurement procedures is becoming a very difficult process, especially if a large number of procurement procedures are carried out at the same time.

Even if the forecast period is reduced very much in the context of the pandemic emergency situation, the use of forecasts over a horizon of at least 10 years (for guidance) or forecast studies over a horizon of 1-10 years can be beneficial. For example, by using methods such as simulation, extrapolation, Delphi technique, correlation, forecasts / studies can be made that could be useful in determining the need for medical materials and equipment to be included permanently in Romania's state reserves. This is also the result of the fact that at the time of the pandemic, the Romanian Government through the Romanian National Administration of State Reserves and Special Problems did not have any emergency stocks of protective materials / equipment (masks, glasses, visors, suits) or disinfectants.

\subsection{THE FUNCTION OF ORGANIZING EMERGENCY PROCUREMENT}

The function of organizing procurement consists of all the processes that establish the activities necessary to carry out the procurement procedures and their distribution on the posts within the procurement compartments, in order to achieve the planned objectives, namely the conduct of the procurement procedures and the provision of necessary products / services. The organizational structures that are created must take into account the real needs of the contracting authority, these being established by documents such as the Organizational Chart, the Organization and Operation Regulations, job descriptions, working procedures.

Robbins \& Coulter (2016) consider that organizing consists in arranging and structuring the work and Bedeian (1989) defines organizing as the process of dividing work into groups and individuals. Nicolescu \& Verboncu (2008) emphasize the establishment and delimitation of intellectual and physical work processes and their components and Moga \& Rădulescu (2004) emphasize that organizing must aim at the efficient use of human, financial and material resources.

In the context of emergency situation generated by the COVID-19 pandemic, the authorized public institutions must have as objectives / responsibilities the conduct of emergency procurement. Such responsibilities did not exist in the organisational documents of any public institution in Romania until the pandemic and the emergency state started.

In Romania, all the procurement compartments / structures within various state authorities are established and are only responsible for the execution of normal procurement, not for the execution of emergency procurement. The same deficiency was found by Guang \& Yi (2012) who noted that in the 
case of China, in crisis situations, procurement compartments have problems in terms of their responsibilities and rights.

Part of the procurement of sanitary materials / equipment were carried out centrally by the Romanian National Office for Centralized Procurement (ONAC), but this institution was established only in 2018 to make centralized procurement at national level, not to carry out public procurement as a matter of urgency. In fact, at present, in Romania there is no public institution that has among its responsibilities the conduct of emergency public procurements. Thus, a number of organizational weaknesses of the structural and procedural configurations can be found with regard to the public authorities authorized to carry out emergency procurement.

Given that procurement compartments need to carry out a large number of procurement procedures as soon as possible, the division of work process is becoming more important and a number of challenges need to be addressed in a context where human resources (procurers) are not supplemented. Often, the press reported cases of public procurers working on emergency procurement procedures until 2 or 3 a.m., which shows that procurers are overloaded with tasks. This overload can lead to unintentional errors, which may result in the submission of appeals, delay or even cancellation of procurement procedures and the purchase of non-compliant products.

Efficient use of human resources is becoming difficult to achieve, especially when no authority hires public procurers only for emergency periods and when the training of a procurer takes at least 3-4 years. The efficient use of financial resources is becoming even more difficult than human resources because, in the crisis situation generated by the COVID-19 pandemic, in Romania (at least at the beginning of the crisis) the production capacity of sanitary materials was very low, large world producers such as China and other countries have stopped exports and closed borders, medical materials I equipment have become very expensive and even a shortage of such sanitary products has appeared. It should be noted that due to the insufficient supply of protective sanitary materials and the lack / noncompliance with working procedures in force, a large number of health professionals have become infected with COVID-19 virus. There have been cases in which the managers of some hospitals in Romania have called for doctors who were confirmed to be sick with COVID-19, which led to the rapid spread of the disease.

In Romania, in order to limit the infection outbreaks during the pandemic, a number of 3 hospitals (Suceava, Deva and Focșani) established military management (Dudescu, 2020). This measure was applied precisely to implement new rules / procedures or to resolve cases of non-compliance with existing working procedures (procedures for wearing protective equipment, disinfection, sorting of patients, etc.). 
Preda, I.

\subsection{THE FUNCTION OF COORDINATING EMERGENCY PROCUREMENT}

The function of coordinating emergency procurement consists in harmonisation of the activities of the staff of procurement compartments and beneficiary structures according to the planning and in the context of pre-established organization.

Popescu (2017) pointed out that the coordination function is ensured by coordinating the organization's activities with the staff activities. Moga \& Rădulescu (2004) consider that the coordination aims to create and maintain (by the manager) the harmony between activities, work compartments and subordinates. Emilian (2003) emphasized the harmonization and orientation of collective and individual efforts and Androniceanu (2005) stressed the importance of organization from the perspective of managing financial, material, informational and human resources.

The coordination of emergency procurement requires optimal communication within procurement compartment and between the procurement compartment and the beneficiary structures. The simultaneous coordination of a large number of procurement procedures requires, first and foremost, feedback from the procurers responsible for conducting procurement procedures.

Optimizing communication in crisis situations requires that the right messages be delivered at the right times. The manager (Head of the procurement compartment) must have a communication style adapted to the needs of the team. To increase trust and connection with subordinates, managers must also deliver negative/disappointing information. Without official information, the risk of spreading rumors and false news is growing greatly and false news can lead managers to wrong decision.

Coordination of emergency procurement also requires the application of a participatory management and must ensure flexibility and adaptability of the activities carried out within the procurement compartment.

In emergency situations, it is very important to have competent, experienced procurers who are very familiar with the legislation in force, the stages of procurement procedures and dedicated IT applications such as the Romanian Electronic Public Procurement System (SEAP).

Emergency procurement requires the rapid spending of significant budgetary funds, which involves significant risks. This makes it necessary for public authorities empowered to carry out emergency procurement to have a dedicated body of procurers, experienced and well trained. Guang \& Yi (2012) noted that the training of procurement practitioners should be strengthened in the event of crisis situations.

Heads of procurement compartments need to be competent and experienced, with proven skills in crisis situations increasing the perception of competence. They must find a balance between speed and deliberation, because the need for rapid decisions is strongest during an emergency. 
In the case of ordinary procurement, the simultaneous conduct of several procurement procedures can be done through an adequate planning of the main moments of their initiation and development (submission of documentation, viewing of offers, analysis of submitted documents, analysis of technical and financial proposals, drawing up the report of the procedure). In the case of emergency public procurement, which must be carried out completely within a very short time, this planning is no longer possible, all these steps taking place at the same time in all procedures. Therefore, whenever necessary, additional checks are needed on the stages of each procedure.

\subsection{THE FUNCTION OF COMMANDING EMERGENCY PROCUREMENT}

The commanding function refers to the work processes by which the staff of the procurement compartments are determined to contribute to the achievement of the objectives.

This function ensures that the first three functions of management are implemented: planning, organising and coordonating (Cicea \& Alexandru, 2008).

Emilian et al. (2004) concluded that in this function managers are considering how to approach, influence and guide the staff, influencing being the only attribute of managers through which they act only on human resources. Moga \& Rădulescu (2004) emphasized that under this function the staff must be selected, trained and attracted to the activities by selecting and using some means of influence. Emilian (2003) defined commanding as the function in which managers determine their staff to use their physical and intellectual resources and Androniceanu (2005) ponited out that in this function human resources are stimulated to contribute to the achievement of the objectives.

Unfortunately, both in the case of regular procurement and emergency procurement, the means of motivation that a manager can use in the field of public procurement are very limited. Even if the manager identifies the needs of the public procurers, the rewards and sanctions he can apply are limited. For example, a ranking system is needed to apply rewards that differentiates procurers on the basis of performance, experience and competence. At present in Romania such a system does not exist.

The financial rewards that can be applied in the area of public procurement are very low. A public procurer who conducts 10 or only 2 procurement procedures in a month shall receive the same salary. Also, procurers are very difficult to dismiss having the status of civil servants, leading to a reluctance by managers to impose sanctions.

In the emergency situation due to the COVID-19 pandemic, unjustified disputes may arise on the grounds of insufficient motivation/incentives. Also, the demotivation of procurers may have the consequences of their lack of cooperation, delays and poor quality of documents produced. 
Preda, I.

Another concern of procurers that emerged during the emergency situaation is that they could have been infected with the COVID-19 virus at the reception of purchased products that had to be touched, handled, especially since many products were delivered by courier services, along with other products / packages.

However, during the pandemic, various financial rewards were applied to other categories of employees. Considering that in Romania on 18.04 .2020 there were 1.031 health professionals infected with COVID-19 virus (meaning 12,25\% of the total number of 8.418 infected persons) (Digi24, 2020a), the Romanian authorities decided to grant medical staff a monthly hazard pay of 500 Euros. Similar measures were taken in other countries such as Kosovo and Bulgaria where additional monthly payments of 300 Euros, respectively 500 Euros were granted (OECD, 2020).

In 2020, the intensity of the planning, organising, coordonating and commanding functions of the public procurement carried out in Romania was higher throughout the pandemic (Figure 3).

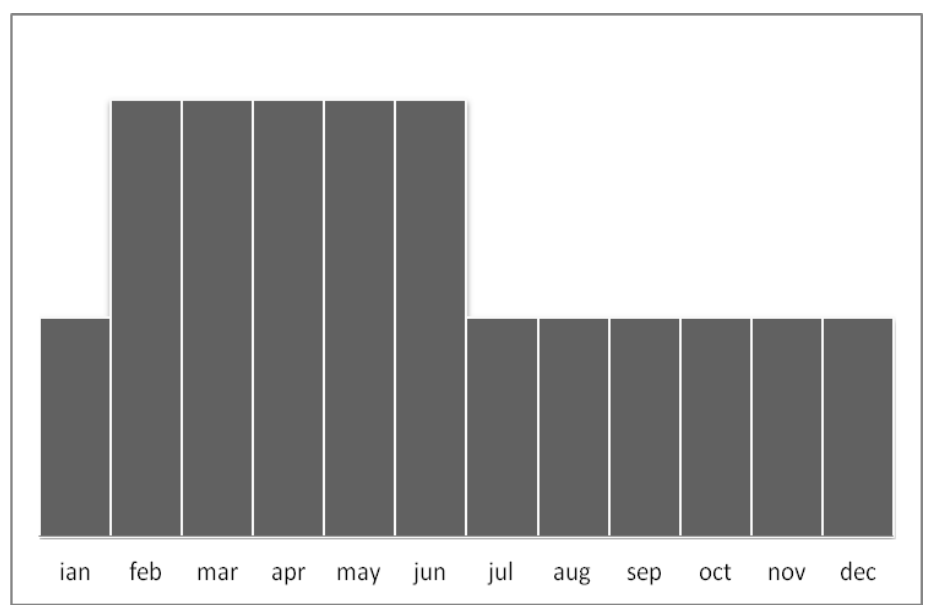

FIGURE 3. REPRESENTATION OF THE INTENSITY OF THE PLANNING, ORGANISING, COORDONATING AND COMMANDING FUNCTIONS OF THE PUBLIC PROCUREMENT

Source: author's conception

\subsection{THE FUNCTION OF CONTROLLING EMERGENCY PROCUREMENT}

This function consists in the processes by which the achievements of procurement compartments are evaluated and compared with the previously established objectives.

In this function is necessary to check the results thoroughly and permanently and to highlight the deviations and the causes that generated them (Popescu, 2017). Also, Emilian et al. (2004) emphasized the importance of directing employees (procurers) to the pre-established tasks.

The function of controlling must be continuous, flexible and preventive, in the context of rigorous compliance with public procurement legislation. 
In Romania, there are a number of persons / institutions performing controls on procurement procedures carried out by procurement departments:

- the head of the procurement compartment;

- internal audit bodies from various public institutions, control bodies of ministers;

- The Romanian National Public Procurement Agency (ANAP), which carries out ex-ante controls;

- The Court of Auditors of Romania, which carries out ex-post controls.

Controls are carried out to verify compliance with public procurement legislation: form of documents, value thresholds, deadlines, stages of the procedures, confidentiality of offers, possible conflicts of interests, etc.

Given that during the COVID-19 pandemic emergency procurement are made in a very short time and at much higher prices than in ordinary procurement, it follows that the risks to honest purchasers are also much higher.

Of course, the speed of procurement, high prices and lack of sanitary materials / equipment on the market can also lead to acts of corruption that must be punished according to the laws in force, but all these risks result in fears for honest procurers.

These fears are due to the fact that unintended errors may occur when procurers are working late at night to perform procurement procedures. Given the very short time available, some procurers may choose to bypass different bureaucratic steps in procurement procedures. Public procurement systems are essentially very slow and bureaucratic systems. Avoiding bureaucracy should be allowed to procure the necessary sanitary materials as soon as possible, especially in a context where it has often been found that the products were only available from a supplier for a few hours after which they were sold to another customer. Reducing the rate of virus spread, protecting health professionals and even saving the lives of infected persons/patients may depend on rapid emergency public procurement.

Other concerns arise from the fact that emergency procurement are made at much higher prices than regular procurement. For example, there have been cases in which protective masks were sold in Romania at prices $1,000 \%$ higher than the pre-pandemic prices. It is very difficult for procurers to prove at any subsequent control what the market prices were for a given product at a certain date and even at a certain time. Ex-post controls take place 1 to 2 years after the respective procurement have been made. A supervisory body can order money to be imputed to honest procurers, motivating this by inefficient or non-economical spending of public funds.

In cases of rapid procurement, there is also the risk of buying substandard products, because the number of institutions in Romania entitled to check medical products is very small. Thus, it is impossible to check the quality of each batch of sanitary materials supplied, especially since during the pandemic 
Preda, I.

the market abounds with counterfeit products precisely due to the increase of prices at national and global level.

These concerns were also expressed in the Romanian media, when a number of officials demanded that during the pandemic "procurers should be granted some kind of protection under the law". Of course, it was not about corrupt procurers, but about committed and brave procurers who carried out rapid procurement, avoided red tape and broke a procedure/rule. Justice officials opposed such a move and stressed that public authorities must prove maximum transparency during the pandemic and that values and standards, including accountability and transparency, should not be compromised (Digi24, 2020b).

Managers/heads of procurement compartments should have competence in crisis management. When people are faced with a crisis situation, a freezing reaction can occur which can lead to difficulties in thinking and blockages in the realization of tasks. This is where indecision, inaction and inefficiency arise.

During the state of emergency, there is much false information that creates confusion and stress for managers. Part of this results from people spreading rumors or using misinformation to try to market products (miraculous solutions to combat the virus appear, the idea that certain products, of competition, are not useful in protecting us from COVID-19) or for other purposes / interests. Rumors can create problems: They stress or create a feeling of insecurity, stress, distrust and individual interests, especially the instinct of preservation, will be at the forefront.

In these circumstances and against the background of these fears, the most serious consequence that may arise is to delay or even not carry out procurement procedure which automatically leads to the spread of the pandemic at national level. Therefore, the need for legal protection of honest procurers is a major necessity. Of course, corrupt procurers who have received bribes or other benefits must be punished according to the laws in force.

\section{SIMPLIFICATION OF EMERGENCY PUBLIC PROCUREMENT PROCEDURES IN ROMANIA}

In Romania, a first measure on emergency public procurement was taken by the Romanian Government by issuing the Government Emergency Ordinance no. 11 / 11.02.2020. Through this act, the Romanian National Office for Centralized Procurement (ONAC) was empowered to carry out centralized procurement procedures for products related to emergency medical stocks.

The chosen procurement procedure was negotiation without prior publication of a contract notice, a noncompetitive procedure which can be applied under conditions of extreme urgency and which consists in inviting only one economic operator to negotiate the prices and the contract terms. An important aspect 
of this procedure is that all contracts can only be concluded for the period necessary to resolve the emergency situation.

Table 1 presents the situation of the number of public procurement procedures completed in Romania between 2017 and 2018.

TABLE 1. NUMBER OF PUBLIC PROCUREMENT PROCEDURES COMPLETED IN ROMANIA BETWEEN 2017 AND 2018

\begin{tabular}{|c|c|c|c|c|c|c|c|c|c|}
\hline \multirow[b]{2}{*}{ No } & \multirow[b]{2}{*}{ Year } & \multirow[b]{2}{*}{ Indicator } & \multicolumn{7}{|c|}{ Types of procurement procedures / number of completed procurement procedures } \\
\hline & & & $\begin{array}{l}\text { Open } \\
\text { auction }\end{array}$ & $\begin{array}{l}\text { Accelerated } \\
\text { open auction }\end{array}$ & $\begin{array}{c}\text { Restricted } \\
\text { auction }\end{array}$ & $\begin{array}{c}\text { Negotiation } \\
\text { with } \\
\text { publication }\end{array}$ & $\begin{array}{c}\text { Negotiation } \\
\text { without } \\
\text { prior } \\
\text { publication }\end{array}$ & $\begin{array}{c}\text { Call for } \\
\text { tenders / } \\
\text { Simplified } \\
\text { procedure }\end{array}$ & TOTAL \\
\hline 1 & 2018 & $\begin{array}{l}\text { Number of } \\
\text { procedures }\end{array}$ & 3,654 & 52 & 11 & 16 & 7,380 & 14,910 & 26,023 \\
\hline 2 & 2018 & $\begin{array}{c}\text { Weight of number } \\
\text { of procedures }\end{array}$ & $14.04 \%$ & $0.20 \%$ & $0.04 \%$ & $0.06 \%$ & $28.36 \%$ & $57.30 \%$ & $100.00 \%$ \\
\hline 3 & 2017 & $\begin{array}{l}\text { Number of } \\
\text { procedures }\end{array}$ & 6,332 & - & 43 & 81 & 3,335 & 13,467 & 23,258 \\
\hline 4 & 2017 & $\begin{array}{c}\text { Weight of number } \\
\text { of procedures }\end{array}$ & $27.23 \%$ & - & $0.18 \%$ & $0.35 \%$ & $14.34 \%$ & $57.90 \%$ & $100.00 \%$ \\
\hline
\end{tabular}

Sources: (ANAP, 2019), (ANAP, 2018)

As can be seen, in the period analyzed before the emergency situation, a significant number of negotiation procedures were carried out in Romania without the prior publication of a participation notice: 7,380 in 2018 (weight 28.36\%) and 3,335 in 2017 (weight 14.34\%).

Following the continued rapid spread of the COVID-19 pandemic, on 16 March 2020 the emergency state was established on Romanian territory by decree of the President of Romania no. 195/2020 which was published in the Romanian Official Gazette no. 212/16.03.2020. The decree established the state of emergency for a period of 30 days throughout Romania as well as a series of measures with immediate and gradual application to combat the spread of COVID-19 virus and to manage the consequences.

The first measures to be applied immediately included the simplification of public procurement procedures, namely the possibility that during the state of emergency a number of public authorities to directly procure equipment and materials needed to combat the COVID-19 pandemic. These authorities were: the public health departments, the central public authorities in which the state is the majority 
Preda, I.

shareholder, the ministries / institutions with their own health system and the health care units (hospitals). The necessary funds were provided through the Romanian Ministry of Health.

Other provisions of the emergency legislation include price caps on medicines, sanitary materials and health equipment necessary to combat the effects of the COVID-19 pandemic and the requisition of their production units.

Public procurement procedures are regulated in Romania by Law no. 98/2016 regarding public procurement. According to this law, direct procurement is not a procurement procedure, but a fast way of purchase that each contracting authority can apply within the value threshold of 135.060 lei, VAT excluded (about 27,900 euros) for procurement of products or services.

In order to carry out a direct procurement, a contracting authority accesses the Romanian Electronic Catalog of Products and Services within the Romanian Electronic Public Procurement System (SEAP), identifies the product / service that can meet its needs, sends an invitation to the respective economic operator (offeror) which may contain the quantity, a maximum price or other conditions of delivery and payment. The offeror may accept or decline this invitation. Depending on the response received from the offeror, the contracting authority shall accept or reject the tenderer's final offer.

The main advantages of direct procurement are speed, transparency, the small number of documents to be drawn up and the fact that the offeror cannot file appeals. The main disadvantages of direct procurement are the lack of quantification of product quality (the award criterion is the lowest price), the lack of a performance guarantee (namely the contracting authority is vulnerable to improper supplier behavior), the direct procurement may also participate offerors with debts to the state's consolidated budget and to the local budget, the fact that many offers in the electronic catalog do not have updated prices and that during the procurement only one economic operator can be invited.

In other countries such as the United Kingdom and the United States, there is a system called "reverse auction" in which several offerors are invited at the same time to bid the same product, lowering the purchase price by a certain deadline set by the contracting authority. Such a system exists in Romania, but it applies only to the final stages of electronic auction within the procurement procedures, not to direct procurement.

The implementation of such a system in the case of regular direct procurement and especially in the case of emergency direct procurement can be very beneficial as it can result in increased competition, reduced corruption and prices and, consequently, significant savings to the state budget. During the state of emergency, the number of suppliers of medical materials and equipment decreases greatly due to the reduction of supply on the free market, so a system to facilitate increased transparency and competition is very necessary. 
Since 18.05.2020, in Romania it went from the state of emergency to state of alert. Thus, the normal procurement regime before the emergency situation was re-established. According to article 5 paragraph (1) point a) of Romanian Law no. 55/2020 on measures to prevent and combat the effects of the COVID-19 pandemic, for the procurement of goods and services of immediate necessity in the management of the emergency situation for which the alert state has been declared, negotiation will be applied without prior publication in compliance with the legislation in the field of public procurement.

Negotiation without prior publication is a procedure that has an average duration. A solution that can improve emergency public procurement is to create a system of registration and pre-qualification of economic operators, so that when the crisis situation occurs, public authorities select offerors from prequalified economic operators, without having to go through a complex procedure procurement and analysis of the situation of tenderers. This can greatly improve the speed and responsiveness of government authorities in the event of crises/pandemics (Guang \& Yi, 2012).

\section{DIFFICULTIES OF EMERGENCY PUBLIC PROCUREMENT}

The coronavirus pandemic has led to a very sharp slowdown of the economies, rising unemployment and poverty. Until the beginning of the pandemic, many sanitary materials were produced outside the EU, especially in China. To reduce their dependence on imports, many European countries have started to produce sanitary protective materials (masks, visors, gloves) and artificial breathing devices.

The general context of emergency public procurement was characterized by a large increase in global demand for medical products, low supply (shortages in some parts of the world), border blockages and especially the increase of corruption.

During the COVID-19 pandemic, following the establishment of the state of emergency and the simplification of procurement procedures, numerous examples of corruption in public procurement or "less moral" procurements appeared in the Romanian media.

Often contracting authorities have preferred to procure non-compliant or sub-standard sanitary materials from some favoured firms. Even the Prime Minister of Romania has warned on various occasions that emergency procurement cannot be made from favored companies, given that centrally purchased medical supplies of good quality are not distributed to hospitals.

The COVID-19 crisis presents many opportunities both for producers and especially for importers and intermediaries. For example, in Romanian, during the emergency, an economic operator who regularly traded cigarettes and alcohol won an open auction for the supply of surgical masks worth $\$ 12.6$ million, at a price twice the market price. This company has established a partnership with a medical equipment supplier who could not participate in the auction because it had debts to the budget. In the US, too, the Federal Emergency Management Agency (FEMA) awarded without an auction a contract for the 
Preda, I.

provision of protective masks at a price of 5,5 dollars/mask, several times higher than the market price (Mediafax, 2020).

Another economic operator selling clothes imported from China 2.2 million FFP1 masks at a price of 1.26 lei / piece (about \$ 0.285 / piece), sold the masks to another company which then sold them to a company of the Romanian Ministry of Health with 2.6 lei / piece (equivalent to \$ 0.59). The price of the masks has practically doubled from the importer to the final customer/consumer (hospitals in Romania). One year before the crisis, the price of a sanitary mask was only $\$ 0.02$ / piece and during the crisis it reached over $\$ 0.2$ / piece at the producer or importer (Luțac \& Tolontan, 2020).

During the state of emergency in Romania, all exports of medical materials / equipment were stopped. However, due to the reduced sanctions provided by law, some companies have tried to export medical products. For example, an economic operator who tried to export the quantity of 50,000 surgical masks to Germany was fined 20,000 lei, a fine that means only 0.4 lei / mask. Considering that at that time the unit price for surgical masks varied between 4 and 6 lei, it follows that due to the low fines amounts, it is profitable for the firm to try to export again (Newsweek, 2020).

Unifarm National Company acquired significant quantities of medical materials from import. For example, between April 6-7, 2020, 300,000 overalls, 2,245,000 FFP2 masks, 2,000,000 surgical masks with 3 plies, 20,000 visors, 923,000 surgical gloves and 36 tons of disinfectants were purchased. Given that worldwide there was a very high demand for sanitary materials, the Romanian Minister of Health stated that "it is a real commercial struggle for the procurement of sanitary materials and equipment on the international market" (Health Minister of Romania, 2020b).

Another problem with the emergency procurement carried out as a result of the COVID-19 pandemic was the verification of the quality of purchased products. Difficulties in the supply of sanitary materials/equipment and cases of delivered products that were of lower quality than requested by the contracting authorities have often been reported.

In Romania, Unifarm National Company withdrew a batch of dangerous masks procured by the company that were manufactured in China. The withdrawal of the batch was made following a European alert issued by the European Medicines Agency (EMEA) and a national alert issued by the Romanian National Association for Consumer Protection (INFOCONS) (Câmpean, 2020). In Spain, 50,000 rapid tests for COVID-19 procured from China were defective and were returned to the producer, with their real failure rate of $70 \%$, well above the producer's maximum failure rate of $20 \%$ (Roman, 2020). In the UK, 250 ventilators procured from China used for artificial respiration had defects such as oxygen supply problems, could not be properly cleaned and could hurt or even kill patients with COVID-19 (g4media, 2020). 
The main causes for such situations were the speed of procurement, the insufficient capacity of the state authorities to check each lot of purchased health product and even the bad intentions of some economic operators. Also, a possible cause of lower quality products is the fact that many firms have tried to take advantage of the opportunities of the crisis and have started to produce sanitary materials that sometimes did not meet the standards in force.

Guang \& Yi (2012) pointed out that during times of crisis, suppliers who behave inappropriately should be severely punished by placing them on "blacklists" that involve a ban on participating in other procurement procedures for a period of 10 years. Such a system exists and is currently applied in the US public procurement system.

\section{CONCLUSIONS}

The research found that the emergency procurement planning function is moving from forecasts to rapid intervention programs and in the case of the organizing function. Until the pandemic and the emergency state started, the public institutions concerned did not have as objectives / responsibilities the conduct emergency procurement. The division of work process also takes on greater importance as human resources (purchasers) are not supplemented.

Coordinating emergency procurement requires better communication and experienced purchasers who know very well the legislation in force. During the pandemic there is much false information, which leads to confusion and stress for managers.

The means of motivation a manager can use during emergency procurement are very limited and this may lead to demotivation.

The controlling function of emergency procurement is characterized by the fact that monitoring of the procurement portfolio is becoming a very difficult process to carry out due to the large number of simultaneous procurement procedures. In these emergency situations some purchasers may choose to avoid different bureaucratic stages of procurement procedures and the risk of buying non-compliant products is much higher.

In Romania, during the pandemic and the state of emergency, there were numerous examples of "less moral" procurement, law violations and corruption: the practice of very large mark-ups by some companies, the procurement of defective or sub-standard medical products and the failure to comply with the measures imposed by the state authorities. 


\section{REFERENCES}

ANAP (2018). Romanian National Agency for Public Procurement. Raport statistic 01 ianuarie - 30 iunie 2018 privind procedurile de atribuire a contractelor de achiziție publică/sectoriale inițiate în cadrul SEAP/SICAP prin publicare de anunț de participare/anunț de participare simplificat/invitație de participare, Retrieved August 27, 2019 from http://anap.gov.ro/web/wpcontent/uploads/2019/01/RAPORT-STATISTIC-APIPAPS-Semestrul-II-2018.pdf

ANAP (2019). Indicatorii de monitorizare a eficienței procedurilor de achiziție publică finalizate prin contract în anul 2018, Retrieved December 2, 2019 from http://anap.gov.ro/web/wpcontent/uploads/2019/09/Indicatori-de-monitorizare-2018_final-23Sep2019.pdf

Androniceanu, A. (2005). Noutăți în managementul public. Editura Universitară

Atkinson, C., L. \& Sapat, A., K. (2012). After Katrina: comparisons of post-disaster public procurement approaches and outcomes in the New Orleans area. Journal of Public Procurement. 12 (3): 356-385

Bedeian, A., G. (1989). Management. Dryden Press, USA

Bozeman, B. \& Kingsley, G. (1998). Risk culture in public and private organizations. Public Administration Review. 58 (2): 109-118

Câmpean, I. (2020). Unifarm a cumpărat măști periculoase produse în China / Compania: Produsele aveau toate certificatele. Nu a fost pus în pericol niciun cadru sanitar sau pacient, iar măștile au fost înlocuite, Retrieved May 6, 2020 from https://www.g4media.ro/unifarm-a-cumparat-mastipericuloase-produse-in-china-compania-produsele-aveau-toate-certificatele-nu-a-fost-pus-in-pericolniciun-cadru-sanitar-sau-pacient-iar-mastile-au-fost-

inlocuite.html?source=biziday\&fbclid=IwAR2loRalulZKPvxQfAu5EGoOP6ehDOrmKes1qIVoSBAwhn dBfp2tThGiEe0

CEFTA (2020). Trade restrictions due to the COVID-19, Retrieved April 11, 2020 from https://cefta.int/COVID-19/\#1489661073289-e1cc8e34-071d

Cicea C. \& Alexandru, G. (2008). Economia. Seria Management. 1:15. Editura ASE

Criss, R. M. (2006). Strategic Sourcing in an Emergency Contracting Environment. Contract Management, 46, (1): 212-224, cited in Atkinson C. L. \& Sapat, A. K. (2012). After Katrina: comparisons of post-disaster public procurement approaches and outcomes in the New Orleans area. Journal of Public Procurement, 12 (3): 356-385

Digi24 (2020a). Peste 1.000 de cadre medicale infectate cu noul coronavirus în România. Retrieved May 2, 2020 from https://www.digi24.ro/stiri/actualitate/peste-1-000-de-cadre-medicale-infectate-cunoul-coronavirus-in-romania-1293909 
Digi24 (2020b). Magistrații cer CSM apărarea independenţei Justiției, după declaraţiile lui Arafat şi Cercel, Retrieved April 28, 2020 from https://www.digi24.ro/stiri/actualitate/magistratii-cer-csmapararea-independentei-justitiei-dupa-declaratiile-lui-arafat-si-cercel1295436?source=biziday\&fbclid=IwAR3IFf1WEDE4UWq69EurXOI9QeDF4cWZG7mIQTj5WWnFfBisew3hj10u9A

Drabkin, D. \& Thai, K. V. (2007). Emergency contracting in the US federal government. Journal of Public Procurement. 7 (1): 84-103

Dudescu, D. (2020). Spitalul Județean Focșani, al treilea din țară care are conducere militară. Nelu Tătaru: „Vrancea nu trebuie să devină o nouă Suceava”'. Retrieved April 30, 2020 from https://www.libertatea.ro/stiri/conducere-militara-la-spitalul-judetean-focsani-nelu-tataru-vrancea-nutrebuie-sa-devina-o-noua-suceava-cine-sunt-medicii-care-coordoneaza-spitalul-2953184

Ellram, L.M. \& Carr, A. (1994). Strategic purchasing: a history and review of the literature. International Journal of Purchasing and Materials Management. 30 (2): 1-9, cited in Pereira, C. L., Christopher, M. \& Da Silva, A. L., (2014). Achievieng supply chain resilience: the role of procurement. Supply Chain Management: An International Journal, 19 (5/6): 626-642

Emilian, R. (2003). Managementul firmei. Editura ASE

Emilian, R., Tigu, G. \& State, O. (2004). Fundamentele managementului firmei. Editura ASE

European Parliament (2014). Directive 2014/24/EU of the European parliament and of the council on public procurement, Retrieved March 15, 2015 from https://eur-lex.europa.eu/legalcontent/EN/TXT/?uriL'OJ:JOL_2014_094_R_0065_01

Expertulbanilor (2020). Curs Euro - Leu, Retrieved May 27, 2020 from https://www.expertulbanilor.ro/curs-valutar-grafic/

Friar, A. (2006). Federal Contracting in Emergencies: A Critical Skill. Contract Management, 46 (3): 2224, cited in Atkinson C. L. \& Sapat, A. K. (2012). After Katrina: comparisons of post-disaster public procurement approaches and outcomes in the New Orleans area. Journal of Public Procurement, 12 (3): $356-385$

g4media (2020). Ventilatoarele din China pot răni sau chiar ucide pacienţi cu Covid-19, avertizează medici britanici, Retrieved May 2, 2020 from https://www.g4media.ro/ventilatoarele-chineze-pot-ranisau-chiar-ucide-pacienti-cu-covid-19-avertizeaza-medici-britanici.html

Guang, Y. \& Yi, M. (2012). The improvement of governmental emergency procurement on resolving public crisis, ICPM - The Proceedings of International Conference Public Management 2012: Crisis in the Time of Changing World, 17-19 August 2012, Kunming, China, 424-429

Health Minister of Romania (2020a). Comunicate de presă, Retrieved May 27, 2020 from http://www.ms.ro/comunicate/ 
Preda, I.

CHALLENGES IN THE MANAGEMENT OF EMERGENCY PUBLIC PROCUREMENT PERFORMED IN ROMANIA TO COMBAT THE COVID-19 PANDEMIC

Health Minister of Romania (2020b). Comunicate de presa. Aprovizionare cu echipamente medicale și materiale sanitare destinate unităților sanitare în lupta împotriva COVID 19, Retrieved April 7, 2020 from http://www.ms.ro/2020/04/07/aprovizionare-cu-echipamente-medicale-si-materiale-sanitaredestinate-unitatilor-sanitare-in-lupta-impotriva-covid-19/

Jin, H., Lu, L., Liu, J. \& Cui, M. (2020). Complex emergencies of COVID-19: management and experience in Zhuhai, China. International Journal of Antimicrobial Agents, 30 (1): 1-2

Lindgreen, A., Vanhamme, J., Van Raaij, E.M. \& Johnston, W.J. (2013). Go configure: the mix of purchasing practices to choose for your supply base. California Management Review, 55(2): 72-96, cited in Pereira, C. L., Christopher, M. \& Da Silva, A. L., (2014). Achievieng supply chain resilience: the role of procurement. Supply Chain Management: An International Journal, 19(5/6): 626-642

Luțac, R. \& Tolontan, C. (2020). Dat afară din SRI, fostul comandor Alexandru Sas a importat, prin firma soției, 2,2 milioane de măști pentru COVID-19 din China, care au ajuns la preț dublu la Unifarm și în spitale. Retrieved April 28, 2020 from https://www.libertatea.ro/stiri/alexandru-sas-firma-sotiei-22milioane-de-masti-china-pret-dublu-2948445

Mediafax (2020). „Pandemie de corupţie”. Ce scrie Washington Post despre afacerile cu măşti din România. Retrieved April 29, 2020 from https://www.mediafax.ro/coronavirus/pandemie-de-coruptiece-scrie-washington-post-despre-afacerile-cu-masti-din-romania19100477?source=biziday\&fbclid=IwAR3ffTjBliLWKqdgKLV3YP2XGAad29i9vkr7aki4Q_DuoNb1Sm2Xd5smRY

Moga, T. \& Rădulescu C. V. (2004). Fundamentele managementului. Editura ASE

Moore, M. (1995). Creating public value: Strategic management in government. London: Harvard University Press, cited in Skipworth, H., Delbufalo, E. \& Mena, C. (2020). Logistics and procurement outsourcing in the healthcare sector: a comparative analysis. European Management Journal, 30 (1): $1-15$

Newsweek (2020). Sibiu: 50.000 de măşti pentru Germania, confiscate de vameşi în Aeroport şi transferate MAI, Retrieved April 22, 2020 from https://newsweek.ro/actualitate/sibiu-50000-de-mastipentru-germania-confiscate-de-vamesi-in-aeroport-si-transferate-mai

Nicolescu, O. \& Verboncu I. (2008). Fundamentele managementului organizației. Editura Universitară OECD (2020). COVID-19 Crisis Response in South East European Economies, Retrieved April 28, 2020 from https://read.oecd-ilibrary.org/view/?ref=129_129649-tclugxbw4j\&title=COVID-19-CrisisResponse-in-South-East-European-Economies

Pereira, C. L., Christopher, M. \& Da Silva, A. L. (2014). Achievieng supply chain resilience: the role of procurement. Supply Chain Management: An International Journal, 19(5/6): 626-642

Popescu, D. (2017). Managementul general al firmei. Editura ASE 
Preda, I.

CHALLENGES IN THE MANAGEMENT OF EMERGENCY PUBLIC PROCUREMENT PERFORMED IN ROMANIA TO COMBAT THE COVID-19 PANDEMIC

Robbins, S., P. \& Coulter, M. (2016). Management thirteenth edition. Pearson Education Limited. Edinburgh Gate, England

Roman, M. (2020). Spania: Scandalul testelor rapide cumpărate din China ia amploare. Au fost 50.000 de teste eșuate, Retrieved March 30, 2020 from https://www.g4media.ro/spania-scandalul-testelorrapide-cumparate-din-china-ia-amploare-au-fost-50-000-de-teste-esuate.html

Romanian Law no. 55/2020 on measures to prevent and combat the effects of the COVID-19 pandemic Romanian Law no. 98/2016 regarding public procurement

Skipworth, H., Delbufalo, E. \& Mena, C. (2020). Logistics and procurement outsourcing in the healthcare sector: a comparative analysis. European Management Journal. 30 (1): 1-15

Vyas, L., Hayllar, M. \& Wu, Y. (2018). Bridging the gap - contractor and bureaucrat conceptions of contract management in outsourcing. Public Organization Review. 18 (4): 413-439 